\title{
Notes on Australian species of Salsola (Chenopodiaceae) and validation of Salsola sabrinae, nom. et stat. nov.
}

\author{
Sergei L. MOSYAKIN \\ M.G. Kholodny Institute of Botany, National Academy of Sciences of Ukraine \\ 2, Tereschenkivska Street, Kyiv (Kiev) 01004, Ukraine \\ s_mosyakin@hotmail.com
}

Mosyakin S.L. Notes on Australian species of Salsola (Chenopodiaceae) and validation of Salsola sabrinae, nom. et stat. nov. Ukr. Bot. J., 2018, 75(1): 3-19.

Abstract. Taxonomic opinions on Australian taxa of Salsola sensu stricto (Chenopodiaceae) are analyzed in a historical context. It is concluded, based on available evidence, that the genus is probably represented in Australia and adjacent regions of southeasternmost Asia by several (4-5 or more) native species, including the currently recognized $S$. australis $\mathrm{R}$. Br. (also naturalized in southwestern North America and southern Africa) and supposedly related taxa (S. macrophylla $\mathrm{R}$. Br., S. brachypteris Moq., S. australis var. strobilifera (Benth.) Domin, etc.); the presence of introduced Eurasian species cannot be excluded as well. The new name Salsola sabrinae Mosyakin is proposed for the native Australian taxon originally described as $S$. tragus L. subsp. grandiflora S. Rilke (non S. grandiflora Link ex Steud.) and reported mainly from northern tropical and subtropical regions of Australia (northern Western Australia, Northern Territory, and Queensland). It is emphasized that further dedicated morphological, molecular phylogenetic, and phylogeographic studies are needed, in comparison with Eurasian species, for achieving a reliable taxonomic scheme for Australian/Australasian species of Salsola and for clarifying issues of their immigration to and diversification in Australia.

Keywords: Australia, biogeography, Chenopodiaceae, nomenclature, Salsola, Salsoloideae, taxonomy

\section{Introduction}

The present contribution is the continuation of two articles recently published in the Ukrainian Botanical Journal (Mosyakin, 2017a, 2017b), in which I already commented on some Australian taxa of Salsola L. sensu stricto (Chenopodiaceae). Salsola is accepted here in its narrow circumscription, following recent molecular phylogenetic findings, partly corroborated by morphological and anatomical data (see Akhani et al., 2007; Wen et al., 2010, Wen, Zhang, 2011; Voznesenskaya et al., 2013; Kadereit et al., 2014; Hernández-Ledesma et al., 2015; Schüssler et al., 2017, and references therein), and nomenclatural stabilization of the taxonomic application of this generic name (Mosyakin et al., 2014, 2017; Mosyakin, 2017a) due to its conservation with $S$. kali L. as the conserved type (Wilson, 2017).

After considering taxonomic and nomenclatural aspects of the names Salsola macrophylla R. Br. and $S$. brachypteris Moq., I stated that "the amazing morphological diversity of Australian Salsola does not fit just one native species now recognized as $S$. australis.

(C) S.L. MOSYAKIN, 2018
Judging from specimens and images I have seen, and from other available evidence (Mueller, 1891; Wilson, 1984; Rilke, 1999; Borger et al., 2008; Chinnock, 2010, etc.), there are at least five native Australian species of Salsola (plus probably one or two introduced ones?)" (Mosyakin, 2017b: 524). In the present follow-up article I consider these and some other native Australian taxa in more detail and provide arguments in favor of the species status of one taxon described as an infraspecific entity (subspecies) from Australia in the end of the $20^{\text {th }}$ century (Rilke, 1999).

Australian taxa of Salsola: a brief overview of taxonomic history

Native Australian plants belonging to Salsola were for the first time observed and collected by Joseph Banks and his party at Bay of Inlets and the Endeavour River (northern Queensland) in 1770 (17 June - 4 August 1770?) during Captain James Cook's first voyage round the world in the HMS Endeavour (see Banks et al., 1905; Pearson, 2005, etc.). They were probably the first Europeans who visited the east coast of Australia. However, earlier visits to that region by some Portuguese and/or Dutch exploration expeditions, results of 
which were mainly kept secret due to the rivalry of European nations in discovery and colonization of new lands, cannot be excluded (see overviews in Pearson, 2005; Magidovich, Magidovich, 2009, etc.), as well as occasional early visitations of native peoples from southeastern Asia (Pearson, 2005; Bean, 2007). In any case, these earlier visits (if we assume that they indeed occurred) left no scientific results in botany; they also can hardly be accepted as possible factors of introduction of Salsola to Australia, and thus we can safely assume that the Salsola plants observed by Banks in 1770 were native.

The plants observed by Banks and later reported as $S$. kali sensu lato were without fruits and their real identity remained uncertain. A color image of "S. kali" is available from Banks' Florilegium produced by Alecto Historical Editions (https://www.alecto-historicaleditions.com/products/ahe-banks-prints-261; see also Banks et al., 1905). This image is based on sketches and notes by Sydney Parkinson, the natural history illustrator of the expedition, who died during the voyage of fever contracted in Java (Pearson, 2005) but before that managed to produce 955 drawings, of which 280 had been converted into full-color watercolors, with botanical notes. Banks later "commissioned five artists to work up Parkinson's field sketches to finished portraits and, for the next thirteen years, employed eighteen engravers to create exquisite copper plate engravings capturing every detail from the original watercolours. By 1784, 743 plates had been completed, but, for a variety of reasons, Banks delayed publication" (see https://www. alecto-historical-editions.com/pages/a-voyage-ofdiscovery). Black-and white images were first published in 1905 (Banks et al., 1905, edited by J. Britten).

The first two Australian taxa of Salsola presumably different from their Eurasian relatives were described by Robert Brown in 1810. Brown, a keen observer and experienced botanist who was definitely familiar with European members of the $S$. kali aggregate, did not hesitate to give species rank to two taxa that he observed and collected in Australia. He described these two entities as $S$. australis $\mathrm{R}$. Br. and $S$. macrophylla $\mathrm{R}$. Br. (Brown, 1810: 411), providing the following diagnoses:

"1. S. australis, herbacea glabra ramosissima, foliis subulatis spinosis divaricatis, bracteis longioribus perianthio solitario; fructiferi alis membranaceis venosis. (J. M.) v. v.

2. S. macrophylla, suffruticosa erecta glabra glauca, foliis subulatis spinosis divaricatis basi triquetrâ, bracteis divaricatis, perianthii fructiferi alis membranaceis. (T.) v. v."
In these diagnoses, "v. v." (vidi vivo) means that Brown observed the living plants during his travel as the naturalist aboard the HMS Investigator in 1801-1803 (Flinders, 1814; Chapman etal., 2001-onward; Vallance et al., 2001; Pearson, 2005, etc.). The abbreviations "J. M." and "T." indicate the regions where the plants were observed and collected (see Brown, 1810: vi-vii; Chapman et al., 2001-onward; Vallance et al., 2001, etc.) in South Australia ( $S$. australis) and Queensland, the East Coast of Australia ( $S$. macrophylla). The type specimens are preserved in $\mathrm{BM}^{*}$ and $\mathrm{K}$, and their digital images are available online:

Salsola australis: http://plants.jstor.org/stable/10.5555/ al.ap.specimen.bm001015878 (lectotype); http://plants. jstor.org/stable/10.5555/al.ap.specimen.k000899587 (isolectotype);

Salsola macrophylla: https://plants.jstor.org/ stable/10.5555/al.ap.specimen.bm000016766 (holotype).

Unfortunately, later researchers mainly ignored Brown's taxa and often accepted all Australian plants of Salsola as S. kali L. sensu latissimo (Bentham, 1870; Mueller, 1891; Boerlage 1900; Banks et al., 1905; Diels, Pritzel, 1905; Ulbrich, 1934; Backer, 1949; Wilson, 1984; Walsh, 1996, and many others), or recently also as $S$. tragus L. sensu lato (Duretto, Morris, 2011; Walsh, Messina, 2015). However, there were also some exceptions.

Moquin-Tandon (1840, 1849) recognized both S. macrophylla and $S$. australis but commented that the latter might be a variety of $S$. kali ("An praecedentis varietas?" - Moquin-Tandon, 1849: 188). He also described from Java (now Indonesia) a new species, S. brachypteris Moq. (Moquin-Tandon, 1840: 147; see also Mosyakin, 2017b), and later reported it from Timor and Australia (Moquin-Tandon, 1849: 189). Before that, Spanoghe (1841:345) listed for Timor only "S. tragus Linn.".

Lehmann (1844: 637) recognized S. macrophylla and reported that Preiss collected this species in 1838 in a sandy area near the mouth of the Swan River, Western Australia: "In arenosis inter frutices ad ostium fluvii Cygnorum, Decembri a. 1838. Herb. Preiss. No. 2396". That was probably the first documented record of a Salsola from Western Australia. A duplicate of this collection is also deposited in the Turczaninow historical herbarium (KW-TURCZ) at the National Herbarium of Ukraine (KW - Herbarium of the M.G. Kholodny Institute of Botany). This specimen (KW001002890) is represented by a terminal or lateral branch ca. $18 \mathrm{~cm}$

* Here and below, herbarium acronyms are given according to Index Herbariorum (Thiers 2018-onward). 
long, with two shorter secondary branches, and has the following label: "Salsola macrophylla R. Br. / nom. pro S. australi habeo! / Nova Hollandia / Preiss. n. 2396 / Remittenda" [the words in bold were added to the original label later, in darker ink]. The plant is definitely not conspecific with $S$. tragus or $S$. kali.

J.D. Hooker (1853: 215-216) recognized S. australis and reported it for the North Island of New Zealand. He also mentioned $S$. brachypteris in his discussion on the tropical Australian flora (Hooker, 1859: xlvi). Mueller (1854) initially listed for Victoria S. australis but later accepted the name $S$. kali for all Australian plants of the genus (Mueller, 1891; see below). Miquel (1855: 1021-1022) reported for the former Dutch East Indies (now Indonesia) and Australia two species, $S$. australis (Timor and Australia; including the misapplied name $S$. tragus auct. listed in synonymy) and $S$. brachypteris (Java, Timor, and Australia). He placed these taxa in different sections (Salsola sect. Kali Dumort. and sect. Soda Dumort., respectively), and distinguished them mainly by their perianth wings: "Alae dilatatae scariosae, perigoni disco vulgo longiores" ( $S$. australis) and "Alae brevissimae unguiformes cartilagineae" (S. brachypteris). Fawcett (1885: 515) also listed for the flora of Timor both $S$. australis and $S$. brachypteris.

Bentham (1870: 207) recognized in Australia only $S$. kali and added the following note: "I can discover nothing to separate the Australian specimens from the European form even as a variety". Despite that note, he himself described two new varieties, $S$. kali var. leptophylla Benth. and var. strobilifera Benth. (Bentham, 1870: 207), and validated a new combination, S. kali var. brachypteris (Moq.) Benth. (Bentham, 1870: 208). Domin (1921: 627-628) used the name S. australis (including $S$. macrophylla, which he considered to be a form or variety), proposed a new combination S. australis var. strobilifera (Benth.) Domin, and briefly mentioned Bentham's var. leptophylla and var. brachypteris.

Bunge (1880) in his biogeographical analysis of Chenopodiaceae, which was amazingly profound for the state of knowledge of the family in those times, noted that the Australian flora contains only two members of "Spirolobeae", including one species of Salsola, which he accepted as $S$. kali. In particular, he commented that "[t]wo [members of] Spirolobeae, Suaeda maritima and Salsola Kali, most likely migrated [rather] late into the coastal areas through human traffic, but were already so modified by local conditions that the former was distinguished as a distinct species, Suaeda australis, while the latter gave reasons for establishment of three

Укр. бот. журн., 2018, 75(1) allegedly separate species: Salsola australis R. Br., macrophylla $\mathrm{R}$. Br., and brachypteris Moq., which were rightly merged again by Bentham" (English translation of: Bunge, 1880: 20**).

Various opinions on the native versus introduced status of Salsola (accepted as $S$. tragus, with $S$. kali cited as a misapplied name) in Australia were summarized by Bean (2007: 18). Keighery (2010: 300) listed S. kali for the Pilbara region (Western Australia) among eight weedy "pan-tropical or cosmopolitan" species with uncertain native/alien status (also listed with this status by Groves et al., 2003) and commented that "[t]hese taxa were most likely introduced before European settlement by Macassan fishermen from Indonesia or by birds from south-eastern Asia (Bean 2007)". However, for a species of Salsola, nothing in the article by Bean (2007) suggests that hypothesis (which may be true for some other species). In his further discussion Keighery (2010), following Borger et al. (2008) and Borger and Scott (2009), accepted $S$. australis as a native species and excluded it from the list of naturalized plants of the Pilbara region.

Extended synonymy and further details on the historical usage of various names applied to Australian representatives of Salsola can be found in Wilson (1984), Borger and Scott (2009), and the Australian Plant Name Index and Australian Plant Census (Council of Heads of Australasian Herbaria, 2006-onward).

Salsola in New Zealand: native/alien status and taxonomy still uncertain?

Early researchers of the flora of New Zealand quite often accepted the name Salsola australis (Hooker, 1853; Adams, 1883, 1897; Armstrong, 1879; Petrie, 1885, 1895; Diels, 1897; Laing, Blackwell, 1906, etc.). In 1870 Kirk (1870) did not list any species of Salsola naturalized in New Zealand in the Auckland area, but later Cheeseman (1883: 291) reported S. kali growing in that area: "Shores of Waitemata and Manukau, not uncommon. Rare at the Thames. (Europe)" (see also Esler, Astridge, 1987). Petrie (1885: 454) in his report of the occurrence of Zoysia pungens Willd. (a synonym of Z. matrella (L.) Merr. sensu lato; however, New

** Original text in German (Bunge, 1880: 20): "Die zwei Spirolobeen: Suaeda maritima und Salsola Kali sind höchst wahrscheinlich erst spät durch Menschenverkehr in die Küstengegenden eingewandert, jedoch durch locale Bedingungen bereits so weit modificirt, dass die erstere als besondere Art, als Suaeda australis unterschieden wurde, während die letztere Veranlassung zur Aufstellung dreier angeblich selbstständiger Arten gab: Salsola australis R. Br., macrophylla $\mathrm{R}$. Br. und brachypteris Moq. welche aber mit Recht von Bentham wieder eingezogen sind". 
Zealand plants are now accepted as Z. pauciflora Mez) and $S$. australis in the Central Otago area of the South Island even suggested that "I think it probable that these littoral plants [both Zoysia and Salsola?-S.M.] have survived in this region of New Zealand since a sea of middle Tertiary age filled up the Manuherikia, Ida, and Maniototo valleys". However, later he (Petrie, 1895: 572) commented that $S$. australis in Otago was "spreading rather rapidly, and most likely introduced". Cheeseman (1906: 587) reported $S$. kali for the North and South Islands with the following note: "Not uncommon on sandy shores from the North Cape southwards, but probably introduced. <...> A widely dispersed plant in most temperate and tropical regions, but of very doubtful nativity in New Zealand. It is a true native of Australia, however".

In recent publications Salsola was considered alien in New Zealand; in particular, Sykes (1982) reported two species as $S$. kali and $S$. ruthenica Iljin (nom. illeg., a synonym of $S$. tragus). The new checklist of the New Zealand flora lists two species, S. kali (naturalized alien) and $S$. tragus (casual alien; with $S$. ruthenica and $S$. pestifer A. Nelson cited in synonymy) (Schönberger et al., 2017). It is not clear yet which species of Salsola in fact occur (or occurs?) in New Zealand.

Salsola tragus and Australian taxa: recent studies and taxonomic changes

Following the publication by Botschantzev (1974), who accepted $S$. australis and cited $S$. tragus subsp. iberica Sennen \& Pau, S. pestifer A. Nelson, S. ruthenica Iljin (nom. illeg.), and $S$. kali subsp. austroafricana Aellen as its synonyms, the name $S$. australis was widely applied (as we know now, misapplied) in the late 1970s-1990s to the most widespread and often weedy species of Salsola, now properly known as $S$. tragus due to its lectotypification and epitypification (see discussion in Rilke, 1999). The recent attempt (Michalková, Letz, 2014) to restore the usage of the Linnaean epithet "tragus" for a Mediterranean coastal taxon (widely known as $S$. pontica (Pall.) Degen or S. tragus subsp. pontica (Pall.) S. Rilke, and now accepted as $S$. squarrosa Steven ex Moq., with three subspecies; see Mosyakin, 2017b) is not taxonomically and nomenclaturally justified (see comments on typification in Rilke, 1999; Mosyakin, 2017a). The application of $S$. australis as the accepted name for the species now recognized as $S$. tragus gradually faded away after publications by Tzvelev (1993, 1996), Mosyakin (1996, 2003b), and Rilke (1999). The status of the native Australian S. australis (also known as alien in California and southern Africa) as a species morphologically and genetically distinct from $S$. tragus was firmly established only after publications of Hrusa and Gaskin (2008), Borger et al. (2008), Borger and Scott (2009), and Ayres et al. (2009), which were partly based on earlier results reported by Ryan and Ayres (2000) and other authors (Ryan et al., 2007; Gaskin et al., 2006).

Thus, the name $S$. australis has become definitely accepted for an Australian taxon after conclusive publications of North American researchers (Hrusa, Gaskin, 2008; Ayres et al., 2009) who identified and studied that taxon introduced in California, and also proved its identity with $S$. kali subsp. austroafricana Aellen (Aellen, 1961: 27) described from Namibia, where it is most probably introduced from Australia. Hrusa and Gaskin (2008) also identified and described a new hexaploid taxon, S. ryanii Hrusa \& Gaskin, which originated in California from hybridization of two aliens, the diploid $S$. australis and the tetraploid $S$. tragus. Now this newly emerged invasive hexaploid is rapidly spreading in California (Welles, Ellstrand, 2016a) and may be expected in adjacent areas. As we can assume from available evidence (Hrusa, Gaskin, 2008; Ayres et al., 2009; Smith et al., 2013), the real patterns of hybridization and emerging speciation in Salsola in California may be even more complicated than it was expected before (see Welles, Ellstrand, 2016b) because hybridization with another Eurasian alien, $S$. paulsenii Litv. (see overview in Mosyakin, 2017a), is also involved. Furthermore, Salsola gobicola Iljin, a stabilized hybrid of $S$. tragus and $S$. paulsenii, is reported spreading in the US Southwest (Mosyakin, 2003b; Hrusa, Gaskin, 2008; Hrusa, 2009, 2012; Cipra, Fuhrmann, 2012; Smith et al., 2013, etc.) and Mexico (Hrusa, 2012).

Recent Australian studies (Borger et al., 2008, 2009; Borger, Scott, 2009; Chinnock, 2010) demonstrated considerable morphological and genetic diversity of Salsola in Australia. Despite that, the authors refrained from nomenclatural conclusions and continued using the name $S$. australis in a wide sense for all native Australian taxa, in accordance with the statement of Chinnock (2010: 78) that "until there is a detailed Australia-wide molecular/taxonomic study of the complex undertaken I consider it foolhardy to try and apply any of the infraspecific names that have been previously proposed under the misapplied names like $S$. kali or $S$. tragus". As a consequence, in recent Australian floras and databases the Australian taxon (in fact, taxa) is accepted either as $S$. tragus (e.g., Duretto, Morris, 2011; Walsh, Messina, 2015) or, more commonly, as $S$. australis sensu lato (e.g., Wightman, Short, 2011; Biggs, Parker, 2013; Jacobs, Murray, 2013; 
Northern Territory Herbarium, 2013-onward; Wilson, Chinnock, 2013; Council of Heads of Australasian Herbaria, 2006-onward, etc.).

\section{Morphological diversity of Salsola in Australia}

After Brown (1810) and Bentham (1870), the morphological diversity of Australian "Salsola kali" has been noted by Ferdinand von Mueller (1891), who illustrated the species (or, better to say, the species aggregate) in the $9^{\text {th }}$ decade of his Iconography of Australian salsolaceous plants. In Plate XC [90] he provided, obviously with the intention to demonstrate patterns of variability of that taxon, rather accurate drawings of plants and their parts, including those of three fruits enclosed in winged perianth segments. All illustrated fruits have perianth segments with large and rather well-developed wings also on the two inner tepals, which seems to be a rather consistent character of many (or all?) native Australian taxa of Salsola (Figure, C). In addition, tips of tepals above the wing plane in the illustrated specimens are very diverse: short and lax, exposing the fruit (Pl. 90, 7, left-hand image), medium-length and somewhat conic (upper central image), and elongated, forming a long but rather lax and not condensed column (right-hand image) somewhat similar to that observed in S. paulsenii Litv. or S. ikonnikovii Iljin (see Iljin, 1936; Rilke, 1999; Zhu et al., 2003, etc.). However, in contrast to Australian taxa, in these and other Asian species the wings on inner tepals are much reduced in size, very narrow and often subulate; the column formed by perianth tips above the wings is narrower and stiffer than in Australian plants. For most of Eurasian taxonomists who worked on Salsola (see Iljin, 1936; Aellen, 1960-1961, 1964; Grubov, 1966; Aellen, Akeroyd, 1993; Rilke, 1999; Freitag, 2001; Mosyakin, 2003b; Zhu et al., 2003; Sukhorukov, 2014; Brullo et al., 2014a, 2014b), such pronounced morphological differences were sufficient enough for recognizing good and distinct species, most of which were also recognized by Rilke (1999) in her detailed taxonomic account of Salsola sensu stricto. However, in Australia these morphological differences were usually ignored, or at least not reflected in accepted taxonomy.

The morphological polymorphism of "S. kali" in Australia was noted by several researchers after Mueller (1891). In particular, Wilson (1984: 316) in his treatment of Chenopodiaceae in the Flora of Australia also commented on polymorphism of Australian "S. kali" sensu latissimo. However, his comments contain some misleading synonymy and because of that his note is cited below in full, with my explanatory comments in square brackets.
"A polymorphic species. Australian material was considered by Aellen (1971 in sched.) to belong to the following taxa: $S$. kali subsp. tragus (L.) Nyman [sensu auct., corresponding to $S$. tragus subsp. pontica sensu Rilke, now Pontic-Mediterranean S. squarrosa, not yet confirmed for Australia - S.M.], S. kali subsp. austroafricana Aellen [now $S$. australis sensu stricto - S.M.], and S. kali subsp. ruthenica (Iljin) Soó [now $S$. tragus sensu stricto, to be expected in Australia as an alien species, but not yet confirmed S.M.]. Botschantzev, op. cit., (1969, 1974), recognised the first of these as a distinct species, $S$. tragus L. [in fact, in 1969 Botschantzev mentioned obscure names "S. tragus Torner" and S. caroliniana Walter, and in his article of 1974 applied (most probably misapplied) the name $S$. caroliniana to the coastal short-winged or wingless species now accepted as $S$. squarrosa - S.M.], and the other two as synonyms of $S$. australis $\mathrm{R}$. Br. [which Botschantzev in 1974 erroneously accepted as the priority name for the taxon previously known as S. pestifer A. Nelson, S. ruthenica Iljin (nom. illeg.), and S. iberica (Sennen \& Pau) Botsch. ex Czerep.; in 1969 he called that species "S. iberica Sennen \& Pau" (nom. inval.); now accepted as $S$. tragus sensu proprio - S.M.]. Salsola kali in the strict sense is not found in Australia. According to Aellen (1961, 1964) subsp. tragus [S. tragus subsp. pontica sensu Rilke, now $S$. squarrosa - S.M.] may be distinguished from subsp. ruthenica by the bracteoles being swollen and connate at the base and the tepals having small or no wings. These distinctions are not readily observable in Australian material, most of which is best placed in $S$. kali subsp. ruthenica [now a synonym of $S$. tragus sensu stricto; in fact, most of Australian specimens probably belong to S. australis - S.M.]" (Wilson, 1984: 316).

Recent molecular and morphological studies of Australian taxa of Salsola (especially Borger et al., 2008; Chinnock, 2010) indicate that there are at least five (and most probably more) entities presumably native to Australia. Borger et al. (2008) by using molecular and partly morphological approaches demonstrated that four rather distinct lineages of Salsola can be recognized in the southwest of Western Australia, which are clearly separated from the studied sample of tetraploid S. tragus sensu stricto (from California). Of these four Australian lineages (all diploids), group A plants were identified as corresponding to $S$. australis sensu stricto, group D was reported as corresponding to the original description of S. macrophylla, and plants of groups B and C remained unclassified, but Borger et al. (2008: 607) mentioned that "both match the description of the former $S$. kali 

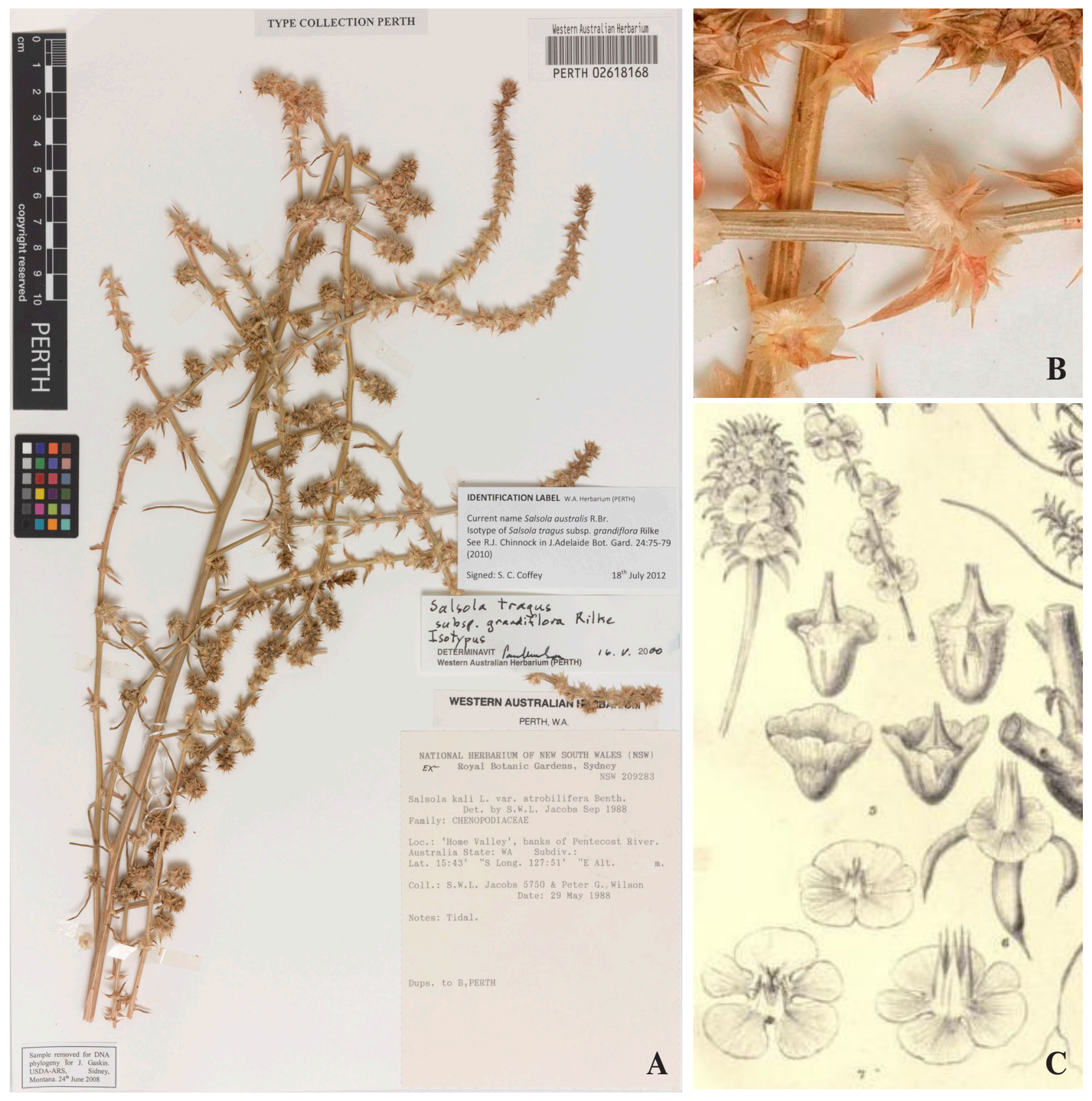

Figure. A: Isotype (PERTH02618168) of Salsola sabrinae Mosyakin (= S. tragus L. subsp. grandiflora S. Rilke). Full-size digital image and collection data are available from http://plants.jstor.org/stable/10.5555/al.ap.specimen.perth02618168 and http:// avh.ala.org.au/occurrences/1f824d56-0e88-416e-a7e4-40018aff5307;

B: fragment of the isotype showing fruits with long tips of tepals above the wings;

C: fragment of Plate XC [90] in Mueller (1891) showing diverse perianth segments in immature (Fig. 5) and mature (Fig. 7) fruits of Australian representatives of Salsola. The lower right perianth (in Fig. 7 of Mueller, 1891; "fruit-bearing calyces") with long tips of tepals above the wings most probably corresponds to $S$. sabrinae or a similar form; other drawings represent $S$. australis and other Australian taxa. Images of PERTH02618168 used with the permission of the Western Australian Herbarium, Department of Biodiversity, Conservation and Attractions (accessed on 6 February 2018) 
var. strobilifera Benth. recognised by Wilson (1984)". No further taxonomic and nomenclatural decisions were proposed.

Chinnock (2010) analyzed patterns of morphological diversity and variability of $S$. australis sensu latissimo in Australia and illustrated some of the revealed morphology-based entities with field photographs. He preliminarily recognized several morphotypes, for which informal names (not the names of taxa!) were proposed. In particular, Chinnock (2010) listed and described the following entities: S. australis subsp. "Coastal", subsp. "Compact", subsp. "Glaucous", subsp. "Lucid", subsp. "Pubescent", and subsp. "Strobilifera". Taxonomic identity of most of those entities remains problematic, but at least three (or four) of them probably already have nomenclaturally available names and should be treated as species.

That is especially true for the "Strobilifera" morphotype, also discussed and listed by Rilke (1999: $131)$ as an informal and unranked entity $S$. tragus "strobilifera". Wilson (1984: 316) provided the following comment on that morphotype: "The name $S$. kali var. strobilifera has frequently been applied to collections in which the fruits are congested in globular to ovoid spikes $\langle\ldots\rangle$. Aellen (1971 in sched.) considered that this variant was a monstrosity that arose independently in different subspecies. Strobiliferous collections are certainly polymorphic and most also have branches with the normal flower arrangement. It is unclear whether or not a distinct taxon is involved". Typical "Strobilifera" plants are apparently restricted to Australia (see Rilke, 1999); they correspond, at least in part, to S. kali var. strobilifera Benth. (S. australis var. strobilifera (Benth.) Domin), but preliminary data of Borger et al. (2008) indicate that there are two genetically distinct but morphologically similar "strobiliferous" lineages, and it is not yet clear to which of those the Bentham's name should be properly applied. Because of that I consider it better to postpone the recognition of this peculiar morphotype as a distinct species, awaiting further research. Meanwhile, the valid name $S$. australis var. strobilifera (see Domin, 1921: 628 [alternative pagination: p. 74]) can be provisionally applied to such forms.

Salsola tragus subsp. grandiflora, a morphologically (and ecologically?) distinct native taxon from Australia

Rilke (1999) reported for Australia only one species, $S$. tragus L. (sensu lato, with $S$. australis cited as a synonym), including subsp. tragus and subsp. pontica (Pall.) S. Rilke native to Eurasia and northern Africa. The names of two taxa described from Australia
(S. macrophylla R. Br.) and Java (S. brachypteris Moq.) were cited as synonyms of $S$. tragus subsp. pontica (Rilke, 1999: 133). However, Mosyakin (2017b) demonstrated that these two species names are definitely not applicable to the Pontic-Mediterranean coastal plants, for which the name $S$. tragus subsp. pontica was accepted by Rilke. Instead, both $S$. macrophylla and S. brachypteris are most probably native Australian/Australasian taxa related to $S$. australis. The species-rank priority name $S$. squarrosa Steven ex Moq. (Moquin-Tandon, 1849: 190) has been restored for the Pontic-Mediterranean taxa, and new nomenclatural combinations $S$. squarrosa subsp. pontica (Pall.) Mosyakin and subsp. controversa (Tod. ex Lojac.) Mosyakin have been proposed (Mosyakin, 2017b: 528).

In addition to two subspecies of $S$. tragus considered introduced in Australia, Rilke (1999) also reported for Australia two other entities, one informal and unranked ( $S$. tragus "strobilifera", more or less corresponding to S. kali L. var. strobilifera Benth. and S. australis subsp. "Strobilifera" sensu Chinnock, see above), and another, which she validly described as the new subspecies $S$. tragus subsp. grandiflora S. Rilke. She provided for subsp. grandiflora the following diagnosis in Latin (Rilke, 1999: 136):

"Differt a subsp. tragus floris grandioris; tepalis 3-4,5(5) $\mathrm{mm}$ longis, 1,2-1,5 $\mathrm{mm}$ latis, marginibus papillosis, exterioribus 3-5nervis, inferioribus $1-3$ nervis. Antheris 1,2-1,9 $\mathrm{mm}$ longis, lobis triangularis $0,09-0,18 \mathrm{~mm}$ longis, thecis e basi $1 / 2-3 / 5$ disjunctis. Fructibus alatis $7-10 \mathrm{~mm}$ diametro; lobis tepalorum supra alarum $2-3 \mathrm{~mm}$ longis, membranaceis, conniventibus, columnam erectam formantibus, columna fere longa quam aliis".

A somewhat more detailed description in German has been also provided. In particular, Rilke (1999: 136) emphasized that plants of subsp. grandiflora have large flowers with tepals 3.0-4.5(5) $\mathrm{mm}$ long and 1.2-1.5 mm wide, papillose at margins; outer tepals with 3-5 nerves, inner ones with 1-3 nerves; anthers 1.2-1.9 $\mathrm{mm}$ long (as opposed to mainly (0.6) 0.8-1.4 (rarely more) $\mathrm{mm}$ long in $S$. tragus subsp. tragus). Fruits are winged, 7-10 $\mathrm{mm}$ in diameter; with tips of tepals above the wings membranous, inclining together, forming an upright column almost as long as wings.

Rilke (1999: 136) also provided additional comments on that taxon (here given in English translation): "This taxon differs by its unusually large tepals, large anthers, and a relatively long column formed by the tepal tips in fruit. Many plants have relatively short bracts and bracteoles, and sometimes the latter are shorter than the 
flowers. However, its morphological differentiation is not (yet) very advanced. Enlargement of flower organs also occurs in $S$. tamamschjanae and occasionally in $S$. tragus subsp. tragus. Geographic differentiation is only beginning to emerge, as the large-flowered populations are predominantly distributed in the subtropical northern part of the Australian continent. The occurrence of subsp. grandiflora in Australia, where its source group was introduced in the $17^{\text {th }}$ century at the earliest, can be viewed as an indication of rapid speciation. The evolution of this taxon was probably driven by polyploidization ${ }^{* * *}$.

However, no chromosome number data have been reported for this taxon yet. All presumably native Australian taxa and morphotypes of Salsola studied so far were diploids with $2 \mathrm{n}=18$ (Borger et al., 2008; Hrusa, Gaskin, 2008; Ayres et al., 2009).

Chinnock (2010: 77) reported S. australis subsp. "Lucid" from the Newman area (Pilbara region, northern part of Western Australia, almost at the Tropic of Capricorn) and noted that this entity "is a dense rounded glabrous (or occasional scattered hairs on branch) shrub with shiny branches and leaves. It is commonly 40 to $80 \mathrm{~cm}$ tall but very large plants to 1.6 $\mathrm{m}$ tall and $3.2 \mathrm{~m}$ across were also observed (Fig. 6). It is characterised by having very shiny leaves and branches and in addition, the developing fruits, unlike other forms of $S$. australis observed, were coloured deep rose in the lower halves of wings (Fig. 7). The size dimensions of these larger plants greatly exceed those given by Wilson (1984) and Borger \& Scott (2009) for the species". Judging from that brief description, and especially from the close-up photograph of a branch with fruits (Chinnock, 2010: 78, Fig. 7), S. australis subsp. "Lucid" is identical with $S$. tragus subsp. grandiflora, which is recognized here as $S$. sabrinae.

\footnotetext{
*** Original text in German (Rilke, 1999: 136): "Diese Sippe unterscheidet sich durch ungewöhnlich große Tepalen, große Antheren und eine relativ lange, von den Tepalenspitzen an der Frucht gebildete Säule. Viele Pflanzen haben relativ kurze Brakteen und Brakteolen, manchmal sind letztere kürzer als die Blüten. Doch ist die morphologische Differenzierung (noch) nicht sehr weit fortgeschritten. Eine Vergrößerung von Blütenorganen kommt auch bei $S$. tamamschjanae und vereinzelt bei $S$. tragus subsp. tragus vor. Eine geographische Differenzierung beginnt sich abzuzeichnen, da die großblütigen Sippen überwiegend im subtropischen Norden des australischen Kontinents verbreitet sind. Das Auftreten der subsp grandiflora in Australien, wohin die Stammsippe frühestens in 17. Jahrhundert eingeschleppt worden ist, kann als Indiz für eine rasche Sippenbildung gewertet werden. Möglicherweise ist Polyploidisierung der Motor für die Entwicklung dieser Sippe".
}

Validation of the new name, and nomenclatural remarks

Salsola sabrinae Mosyakin, nom. et stat. nov. $\equiv$ Salsola tragus L. subsp. grandiflora S. Rilke, Biblioth. Bot. 149: 135 (description on page 136). 1999 (non Salsola grandiflora Link ex Steud., Nomencl. Bot., ed. 2, 2: 502. 1841).

Type (holotype, see Rilke, 1999: 135): Western Australia, Home Valley, banks of Pentecost River, $15^{\circ} 43^{\prime} \mathrm{S}$ $127^{\circ} 51^{\prime}$ E, 29.5.1988, Jacobs \& Wilson NSW-209283 (NSW, image available from http://plants.jstor.org/ stable/10.5555/al.ap.specimen.nsw209283, isotypes in B and PERTH - http://plants.jstor.org/stable/10.5555/ al.ap.specimen.perth02618168, Figure, A, B).

Informal (invalid) name applied to $S$. sabrinae:

Salsola australis R. Br. subsp. "Lucid" Chinnock, J. Adelaide Bot. Gard. 24: 77. 2010, nom. inval. (not intended as a taxon name, provisional; Art. 36.1(b) of the ICN: McNeill et al., 2012; see Chinnock, 2010: 77-78).

Published images: Chinnock (2010: 78, Figs. 6 and 7), as Salsola australis R. Br. subsp. "Lucid". Probably also Mueller (1891: Plate XC [90], Fig. 7, right-hand image).

Distribution (data probably incomplete): tropical and subtropical regions of Australia: Western Australia (north), Northern Territory, Queensland (see Rilke, 1999; Chinnock, 2010).

Habitats: open sandy or sandy-clayey areas: sand dunes, sandy river banks, roadsides, disturbed and ruderal sandy habitats.

The name Salsola grandiflora Link ex Steud. (Steudel, 1841: 502) was validly published with the reference to "S. Soda. Brot.", which can be interpreted as indirect reference to the Latin description of Salsola soda sensu Brot. (Fl. Lusit. 1: 404. 1804), non L. (Brotero, 1804). Consequently, the epithet "grandiflora" cannot be used for another species in Salsola because of the existing earlier homonym (Art. 53.1 of the ICN: McNeill et al., 2012). The new name is given to the Australian species in recognition of the valuable contributions of Sabrina Rilke to the taxonomy of Salsola (Rilke, 1999).

Most probably Rilke validated that taxon as a subspecies of $S$. tragus because she was hypnotized (as well as almost all other researchers) by the opinion that all taxa of Salsola occurring in Australia are just alien species that recently migrated from Eurasia during the European colonization of the continent. Now we know for sure that there are native taxa of Salsola occurring in Australia, and several of them, including $S$. sabrinae, deserve the species rank. 
Morphological peculiarities of Salsola sabrinae: possible ecological explanations?

It is interesting to hypothesize on the possible adaptive significance of the peculiar characters of the fruiting perianth of $S$. sabrinae, especially its unusually large wings and a long column formed by perianth tips above the wings. Rilke (1999) reported that subsp. grandiflora prefers mostly open and often disturbed sandy habitats, such as sand dunes, sandy river banks, roadsides, etc. In my opinion, the mentioned morphological features might be indeed adaptive for Salsola plants growing in open sandy habitats and under hot and dry environmental conditions.

A long column of perianth tips and usually large wings are also peculiar characters of some Eurasian species of Salsola, such as $S$. paulsenii Litv., S. praecox (Litv.) Iljin (= S. kali var. praecox Litv.; S. paulsenii subsp. praecox (Litv.) S. Rilke), and S. ikonnikovii Iljin (see Iljin, 1936; Grubov, 1966; Rilke, 1999; Zhu et al., 2003, etc.). All these taxa usually occur in open sandy areas in arid regions, where climatic conditions during the vegetation period of these plants are often hot and dry. It is possible that large tepals, with their upper parts covering the developing gynoecium, protect it from dehydration due to high air temperatures and solar radiation (both direct and reflected from the sand surface). It is also possible that the long perianth tips may protect the gynoecium against mechanical damage by sand grains moved by the wind.

Winged perianth in Salsola is an obvious morphological adaptation to anemochory, dispersal of fruits by wind (Rilke, 1999; Toderich et al., 2012; Sukhorukov, 2014; Sukhorukov et al., 2015). Species of Salsola are characterized by some balance of two syndromes and strategies of wind dispersal: (1) typical anemochory (also meteor-anemochory or anemometeorochory; wind-dispersed fruits enclosed in winged perianth - pterometeorochory in the strict sense) and (2) chamaechory (or chamae-anemochory; wind-assisted dispersal by rolling along the ground, tumbleweeds in Salsola) (van der Pijl, 1982; Vittoz, Engler, 2007). Thus, species with prominently winged tepals invest more in the typical anemochory (pterometeorochory) strategy, while in tumbleweedforming species the direct dispersal of individual winged diaspores is probably less important, and their perianth wings are often smaller than in non-tumbleweed taxa. According to the aerodynamic classification of seed and fruit groups (Burrows, 1975), taxa of Salsola match group C ("plain winged seeds and fruits with a central or more or less central concentration of mass") and group E ("seed-carrying tumble weeds"). Tumbleweedforming species occur in several families of plants (such as Amaranthaceae, Amaryllidaceae, Asteraceae, Brassicaceae, Chenopodiaceae, Fabaceae, Lamiaceae, Poaceae, etc.), but, despite several recent studies (see Burrows, 1975; Becker, 1978; Baker et al., 2008, 2010; Damschen et al., 2014, Borger et al., 2007, etc.), some important details of this dispersal mechanism still remain insufficiently understood.

In some species of Salsola, fruits with both winged and almost wingless perianth segments can be often observed even on the same plant (heteroflory/heterocarpy, dimorphism or polymorphism of diaspores: see Rilke, 1999; Sukhorukov, 2014, etc.). Probably these different types of fruits reflect different dispersal strategies, which are important for survival and propagation of plants in populations growing in fragmented and marginal habitats with rapidly changing and often unpredicted environmental conditions. Salsola species (or populations?) restricted to linear (in particular, coastal) habitats tend to have fruits with wingless or shortwinged tepals, and that feature has its possible ecological explanations (see below). Widespread generalist species with ruderal life strategies, such as $S$. tragus, may in fact use two dispersal strategies: winged diaspores (mainly developing on the upper parts of the plant) are dispersed individually while wingless or short-winged diaspores (usually located closer to the plant base) remain on the plant until the end of the vegetation season and are dispersed from tumbleweeds moving over the ground.

Considering dispersal modes of different taxa of Corispermum L. having broadly winged or wingless fruits, I concluded that "species with winged fruits [diaspores] have selective advantages in those cases when suitable habitats occupy large areas and are easily accessible $<\ldots>$. However, when such suitable areas are limited and surrounded by unfavorable habitats $\langle\ldots\rangle$, then this advantage turns into its opposite, and the selective press will favor narrow-winged or completely wingless forms and species. <...> "Tactical tasks" of dispersal at close distances and successful occupation of already colonized habitats and the "strategic tasks" of long-distance dispersal are implemented [at least in Corispermum] by the dynamic balance of two major types of anemohory-direct wind dispersal of fruits $\langle\ldots\rangle$ and wind-assisted dispersal of the whole aboveground part of the plant (tumbleweed)" (translated from Ukrainian: Mosyakin, 2003c: 260-261).

There are three main hypotheses explaining advantages of dispersal in plants and dispersal-associated morphological and physiological adaptations (see 
Howe, Smallwood, 1982; Eriksson, Kiviniemi, 1999; van Rheede van Oudtshoorn, van Rooyen, 1999; Schupp, 2011, etc.). The Directed Dispersal hypothesis assumes targeted dispersal of diaspores to predictably favorable locations, usually by some vector; it is not directly applicable to Salsola. The Colonization hypothesis suggests that populations obtain selective advantages because of their spatial expansion and dispersal to new or distant habitats. This hypothesis is directly applicable to many invasive species and plants with ruderal life strategies (Grime, 1977; Grime, Pierce, 2012), including species of Salsola. The Escape hypothesis (also Janzen-Connell hypothesis) emphasizes the advantages associated with escaping the vicinity of parent plants (see Howe, Smallwood, 1982; Eriksson, Kiviniemi, 1999; van Rheede van Oudtshoorn, van Rooyen, 1999; Schupp, 2011, etc.), such as reduced competition between parent and offspring plants, reduced chances of mortality in overcrowded habitats due to predation (herbivory) and pathogens, and reduced chances of gene exchange with close relatives. However, in the case of coastal plants of Salsola with short-winged or wingless perianth segments, these potential benefits of escaping the negative effects of the parent site are probably not so significant as compared to benefits of establishing and maintaining stable colonies in suitable linear (ribbon) coastal habitats in or near the parent site instead of wasting limited resources of available diaspores by their fruitless dispersal to unsuitable inland habitats, or just to the sea.

Judging from its morphology (in particular, prominently winged tepals), Salsola sabrinae should be a species well adapted to wind dispersal of individual diaspores (fruits enclosed in perianth), which are easily detached from the plant at maturity. Thus, it should rarely (or never?) form typical tumbleweeds easily separated from the root at senescence. However, tumbleweed formation in Salsola may also be partly dependent on environmental conditions.

In my opinion, Salsola sabrinae can be viewed as a morphological and ecological analogue of Eurasian psammophytic species, such as $S$. paulsenii and $S$. praecox, which are characterized by similar morphological adaptations of their perianth (large wings and long tips of tepals). Most probably these characters resulted from parallel evolution and developed independently in Australian and Eurasian psammophytes. Salsola sabrinae is easily distinguished from $S$. paulsenii and other Eurasian species in having larger wings on inner tepals, similar to those in S. australis sensu stricto.
The difference in the modes of formation of tumbleweeds in $S$. tragus and $S$. australis was also noted by Hrusa and Gaskin (2008). Seed/fruit dispersal characteristics of $S$. australis were studied in Australia (Borger et al., 2007) and compared with available data on S. tragus (Schmidt, Reeves, 1989; Stallings et al., 1995) and S. paulsenii (Young, Evans, 1979) obtained mainly in North America, but these studies were carried out only on Western Australian populations representing "the most common agricultural weed form that is found throughout Australia" (Borger et al., 2007: 413). Now it would be interisting to compare dispersal modes and characteristics of several Australian taxa differing in their morphology and ecology. Special comparative studies of dispersal modes and strategies in different species of Salsola using modern ecological approaches (see Bullock et al., 2006) may bring interesting results important for plant dispersal ecology, biogeography, and weed control.

\section{Concluding remarks and tasks for the future}

In their assessment of the origin and possible age of some Australian representatives of Chenopodiaceae Kadereit et al. (2005: 75) commented on Salsola that "[t]here can be no doubt that many Australian populations are offspring from introductions, but the species was already present at the beginning of the $18^{\text {th }}$ century in Australia [in fact, no reliable records before 1770, see above-S.M.] and might have settled there just before the arrival of Europeans. $<\ldots>$ The species could have arrived by long-distance dispersal from the eastern part of its area, either from C Asia or from Pakistani Baluchistan". However, no special studies of Australian Salsola in comparison to Eurasian relatives have been done within that project and no specific evidence-based age estimates have been provided.

Anyway, considering the expected rates of evolution of annual (or short-lived perennial) plants of coastal, marginal and other rapidly changing dynamic habitats, we can conclude that even a comparatively short geological time span, e.g., since the late Pleistocene or even the early Holocene, was sufficient for emergence of several species of Salsola not less distinct from each other than many of their congeners readily and reliably recognized in Eurasia. Many other cases of spectacular and quite recent (in terms of the geological timescale) morphological and phylogenetic radiation of representatives of Chenopodiaceae in Australia, especially in better studied representatives of Camphorosmeae and Salicornioideae, were discussed in recent publications (see Shepherd et al., 2004, 2005; Cabrera et al., 2009, 2011; Kadereit, Freitag, 2011; 
Kadereit et al., 2014; Piirainen et al., 2017; Mosyakin, Iamonico, 2017, and references therein). Phylogenybased reconstructed migration patterns of many other taxa occurring in remote areas of the Southern Hemisphere also indicate that long-distance and/or step-stone dispersal events followed by fast evolutionary radiations played an important role in shaping the current patterns of geographical disjunctions and centers of diversity in vascular plants (see examples and case studies in Cain et al., 2000; Winkworth et al., 2002, 2015; Mosyakin et al., 2007; Stuessy et al., 2014; Mosyakin, Iamonico, 2017; Murphy, Crayn, 2017; Ebach, 2017, and references therein).

Australian records of fossil pollen of Chenopodiaceae are rich, and representatives of the family undoubtedly played an important role in the history of formation and development of Australian vegetation, but in most cases the fossil pollen grains were identified and reported only as "Chenopodiaceae pollen" or chenopod/ amaranth pollen" (Kadereit et al., 2005; Martin, 2006; Macphail, 2007; Hill et al., 2017, etc.). Macrofossils of Salsola and other Salsoleae are extremely rare anywhere (see Kadereit et al., 2003; Akopian et al., 2008 and references therein), but, if found and identified in the Australian deposits dated by at least the Pleistocene or early Holocene, or in more recent pre-European archaeological sites, they will be undeniable evidence of the native status of Salsola in Australia. In a similar case of uncertain native/alien status of Corispermum in North America, fossil evidence (Betancourt et al., 1984), in combination with recognition of several rather diverse native taxa (see Mosyakin, 1995, 2003a), was the ultimate proof of pre-Columbian presence of the genus in the New World. Until now, no evidence of prehistoric uses of Salsola in Australia has been reported (see McConnell, 1998 and references therein). Salsola is also not mentioned in a historical inventory of useful plants of Australia and their uses by Indigenous people and European settlers (Maiden, 1889).

At present, three (or four, if $S$. brachypteris from Indonesia is also considered) native species of Australian Salsola have valid species-rank names: $S$. australis (which is now widely recognized), S. macrophylla (status uncertain, but most probably a distinct species related to $S$. australis), and $S$. sabrinae (accepted in the present article). Some additional native species (such as "Strobilifera" morphotypes, etc.) will be probably recognized following further research, and the presence of some Eurasian aliens ( $S$. tragus and/or related taxa) cannot be excluded as well. A large-scale study is needed for representative Australian material, selected Eurasian and newly emerged North American taxa, using molecular phylogenetic, phylogeographical, morphological and karyological approaches. It should also include field studies in populations in order to obtain information about infraspecific variability. Such study will clarify relationships with extra-Australian species, possible routes of colonization of the Australian continent by taxa of Salsola, the origin and divergence times of the Australian taxa, as well as their taxonomy. For comparison, special attention should be paid to Central Asian taxa, those occurring in southern (e.g., Pakistan: S. paulsenii and $S$. praecox, etc.) and eastern (diploid S. collina Pall., coastal East Asian S. komarovii Iljin) regions of Asia, as well as to widespread coastal and weedy species. Integral parts of this study should be (1) critical re-assessment of historical type specimens and other original material to ensure the proper application of names to Australian taxa to be recognized, and (2) re-evaluation of the rich Australian herbarium material in order to recheck and to define or re-define morphology-based entities, including those that so far escaped attention of earlier researchers (at least partly). The resulting numerous new identifications of Salsola collections in the Australian and other herbaria would become a reliable reference for scientists and other professionals interested in these plant species.

\section{Acknowledgments}

I am grateful to Prof. Helmut Freitag (University of Kassel, Germany) for discussing some issues of taxonomy and nomenclature of Salsola, and especially for his valuable comments on the manuscript, and to Prof. Ladislav Mucina (University of Western Australia, Perth, Western Australia, Australia) for providing preliminary information on some unusual Australian forms of Salsola. Dr. Catherine Borger (Department of Primary Industries and Regional Development (Agriculture and Food), Perth, Western Australia, Australia), Prof. Darren Crayn (James Cook University, Cairns, Queensland, Australia) and Dr. Neville Walsh (Royal Botanic Gardens Victoria, Melbourne, Victoria, Australia) provided copies of their valuable publications, and their help is gratefully acknowledged. Thanks are due to Dr. John Huisman (Western Australian Herbarium, Department of Biodiversity, Conservation and Attractions, Kensington, Western Australia, Australia) for his permission to reproduce here the digital image of the isotype (PERTH02618168). Prof. Helmut Freitag (University of Kassel, Germany) and Prof. Vasyl P. Heluta (M.G. Kholodny Institute of Botany, National Academy of Sciences of Ukraine, Kyiv, Ukraine) kindly suggested better variants of translation of some 
terms and phrases in German texts. Thanks are due to an anonymous reviewer for his/her useful comments on the manuscript.

\section{REFERENCES}

Adams J. On the Botany of the Thames Goldfields. Transactions and Proceedings of the New Zealand Institute, 1883 [published 1884], 16: 385-393.

Adams J. On the Botany of Hikurangi Mountain. Transactions and Proceedings of the New Zealand Institute, 1897 [published 1898], 30 (13 in New Ser.): 414-433.

Aellen P. Chenopodiaceae. In: G. Hegi. Illustrierte Flora von Mitteleuropa. Aufl. 2. München: Lehmann Verlag, 19601961 (Reprinted in 1979: Berlin; Hamburg: Paul Parey Verlag), Bd. 3, T. 2, pp. 533-747.

Aellen P. Neue Chenopodiaceen aus Südwestafrika. Mitteilungen der Botanischen Staatssammlung München, 1961, 4: 21-31.

Aellen P. Salsola. In: Flora Europaea. Eds. T.G. Tutin, V.H. Heywood, N.A. Burges, D.H. Valentine, S.M. Walters, D.A. Webb. Cambridge: Cambridge Univ. Press, 1964, vol. 1, pp. 104-107.

Aellen P., Akeroyd J.R. Salsola. In: Flora Europaea. Ed. 2. Eds. T.G. Tutin, N.A. Burges, A.O. Chater, J.R. Edmondson, V.H. Heywood, D.M. Moore, D.H. Valentine, S.M. Walters, D.A. Webb. Cambridge: Cambridge Univ. Press, 1993, vol. 1, pp. 125-128.

Akhani H., Edwards G., Roalson E.H. Diversification of the Old World Salsoleae s.l. (Chenopodiaceae): molecular phylogenetic analysis of nuclear and chloroplast data sets and a revised classification. International Journal of Plant Sciences, 2007, 168(6): 931-956. http://dx.doi.org/10.1086/518263

Akopian J., Gabrielyan I., Freitag H. Fossil fruits of Salsola L. s.l. and Halanthium K. Koch (Chenopodiaceae) from Lower Pleistocene lacustrine sediments in Armenia. Feddes Repertorium, 2008, 119(3-4), 225-236. http:// dx.doi.org/10.1002/fedr.200811164

Armstrong J.B. A short sketch of the flora of the Province of Canterbury, with catalogue of species. Transactions and Proceedings of the New Zealand Institute, 1879 [published 1880], 12: 325-353.

Ayres D., Ryan F.J., Grotkoo E., Bailey J., Gaskin J. Tumbleweed (Salsola section Kali) species and speciation in California. Biological Invasions, 2009, 11: 1175-1187. http://dx.doi.org/10.1007/s10530-008-9380-5

Backer C.A. Chenopodiaceae. In: Flora Malesiana, series 1: Spermatophyta. Ed. C.G.G.J. van Steenis. Batavia: Noordhoff-Kolff N.V., 1949, vol. 4(2), pp. 99-106.

Baker D.V., Beck K.G., Bienkiewicz B.J., Bjostad L.B. Forces necessary to initiate dispersal for three tumbleweeds. Invasive Plant Science and Management, 2008, 1(1): 5965. https://doi.org/10.1614/IPSM-07-009.1

Baker D.V., Withrow J.R., Brown C.S., Beck K.G. Tumbling: use of diffuse knapweed (Centaurea diffusa) to examine an understudied dispersal mechanism. Invasive Plant Science and Management, 2010, 3: 301-309.

Banks J., Solander D. (with determinations by J. Britten). Illustrations of Australian plants collected in 1770 during Captain Cook's voyage round the World in H.M.S. Endeavour. London: Printed by order of the
Trustees of the British Museum, sold by Longmans, 1905, vol. 3, pp. 77-102+ Pl. 244-318.

Bean A.R. A new system for determining which plant species are indigenous in Australia. Australian Systematic Botany, 2007, 20: 1-43.

Becker D.A. Stem abscission in tumbleweeds of the Chenopodiaceae: Kochia. American Journal of Botany, 1978, 65: 375-383.

Bentham G. Chenopodiaceae. In: Flora Australiensis: a description of the plants of the Australian territory. London: Reeve and Co., 1870, vol. 5, pp. 150-208.

Betancourt J.L., Long A., Donahue D.J., Jull A.J.T., Zabel T.H. Pre-Columbian age for North American Corispermum L. (Chenopodiaceae) confirmed by accelerator radiocarbon dating. Nature, 1984, 311: 653-655.

Biggs L.J., Parker C.M. Updates to Western Australia's vascular plant census for 2012. Nuytsia, 2013, 23: 503-526.

Boerlage J.G. Handleiding tot de kennis der flora van Nederlandsch Indië. Beschrijving van de families en geslachten der Nederl. Indische phanerogamen. Leiden: E.J. Brill, 1900, vol. 3(1), xxxi + 418 pp.

Borger C.P.D., Scott J.K. The biology of Australian weeds. 55. Salsola australis R.Br. Plant Protection Quarterly, 2009, 24(4): 126-137.

Borger C.P.D., Scott J.K., Walsh M., Powles S.B. Demography of Salsola australis populations in the agricultural region of south-west Australia. Weed Research, 2009, 49(4): 391-399. http://dx.doi. org/10.1111/j.1365-3180.2009.00702.x

Borger C.P.D., Walsh M., Scott J.K., Powles S.B. Tumbleweeds in the Western Australian cropping system: seed dispersal characteristics of Salsola australis. Weed Research, 2007, 47: 406-414.

Borger C.P.D., Yan G., Scott J.K., Walsh M., Powles S.B. Salsola tragus or $S$. australis (Chenopodiaceae) in Australia - Untangling the taxonomic confusion through random amplified microsatellite polymorphism (RAMP) and cytological analysis. Australian Journal of Botany, 2008, 56: 600-608. http://dx.doi.org/10.1071/BT08043

Botschantzev V.P. The genus Salsola L., a short history of its development and dispersal. Botanicheskiy Zhurnal, 1969, 54(7): 989-1001. [Бочанцев В.П. Род Salsola L., краткая история его развития и расселения. Ботанический журнал, 1969, 54(7): 989-1001].

Botschantzev V.P. A synopsis of Salsola (Chenopodiaceae) from South and South-West Africa. Kew Bulletin, 1974, 29: 597-614. http://dx.doi.org/10.2307/4108004

Brotero de Avellar F. Flora lusitanica, seu Plantarum, quae in Lusitania vel sponte crescunt, vel frequentius coluntur, ex florum praesertim sexubus systematice distributarum, synopsis. Olissipone [Lisbon]: Typographia regia, 1804, vol. 1 , xviii +607 pp.

Brown R. Prodromus florae Novae Hollandiae et Insulae Van-Diemen. Londini [London]: Typis Richardi Taylor et socii, 1810, viii + pp. 145-590.

Brullo C., Brullo S., Gaskin J.F., Giusso del Galdo G., Hrusa G.F., Salmeri C. A new species of Kali (Salsoloideae, Chenopodiaceae) from Sicily, supported by molecular analysis. Phytotaxa, 2015a, 201(4): 256-277. http://dx.doi.org/10.11646/phytotaxa.201.4.2 
Brullo C., Brullo S., Ilardi V., Giusso del Galdo G. Kali dodecanesicum (Chenopodiaceae, Salsoloideae) a new species from Greece. Phytotaxa, 2015b, 218(1): 61-68. http://dx.doi.org/10.11646/phytotaxa.218.1.4

Bullock J.M., Shea K., Skarpaas O. Measuring plant dispersal: an introduction to field methods and experimental design. Plant Ecology, 2006, 186: 217-234. http://dx.doi. org/10.1007/s11258-006-9124-5

Bunge A. Pflanzen-geographische Betrachtungen über die Familie der Chenopodiaceen. Mémoires de l'Académie Impériale des Sciences de St.-Pétersbourg. 7e série, 1880, 27(8): 1-36.

Burrows F.M. Wind-borne seed and fruit movement. New Phytologist, 1975, 75: 405-418.

Cabrera J.F., Jacobs S.W.L., Kadereit G. Phylogeny of the Australian Camphorosmeae (Chenopodiaceae) and the taxonomic significance of the fruiting perianth. International Journal of Plant Sciences, 2009, 170: 505-521.

Cabrera J., Jacobs S.W.L., Kadereit G. Biogeography of Camphorosmeae (Chenopodiaceae): tracking the Tertiary history of Australian aridification. Telopea, 2011, 13(12): 313-326.

Cain M.L., Milligan B.G., Strand A.E. Long-distance dispersal in plant populations. American Journal of Botany, 2000, 87(9): 1217-1227.

Chapman A.R., Moore D.T., Rees R.G., Groves E.W. Robert Brown's Australian botanical specimens, 18011805 , at the BM. Introductory notes to the botanical collection made by Robert Brown (1773-1858) in Australia, 1801-1805. 2001-onward. Available from https://florabase.dpaw.wa.gov.au/brown/, accessed 26 January 2018.

Cheeseman T.F. The naturalized plants of the Auckland Provincial District. Transactions and Proceedings of the New Zealand Institute, 1982 [published 1883], 15: 268-298.

Cheeseman T.F. Manual of the New Zealand Flora. Wellington: John Mackay, Government Printer, 1906, xxxvi + 1199 pp.

Chinnock R.J. Some observations on Salsola L. (Chenopodiaceae) in Australia. Journal of the Adelaide Botanical Garden, 2010, 24: 75-79.

Cipra J., Fuhrmann K. Understanding endangered plant species population changes at Eureka Dunes, Death Valley National Park. Park Science, 2012, 29(1): 62-68.

Council of Heads of Australasian Herbaria. National Species List (Australian Plant Name Index and Australian Plant Census), 2006-onward. Salsola australis R. Br. Available from https://biodiversity.org.au/nsl/services/name/ apni/60062/api/apni-format and https://id.biodiversity. org.au/name/apni/60062, accessed 28 January 2018.

Damschen E.I., Baker D.V., Bohrer G., Nathan R., Orrock J.L., Turner J.R., Brudvig L.A., Haddad N.M., Levey D.J., Tewksbury J.J. How fragmentation and corridors affect wind dynamics and seed dispersal in open habitats. Proceedings of the National Academy of Sciences of the USA, 2014, 111(9) 3484-3489. https://doi. org/10.1073/pnas.1308968111

Diels L. Vegetations-Biologie von Neu-Seeland. Botanische Jahrbücher fur Systematik, Pflanzengeschichte und Pflanzengeographie, 1897, 22: 202-300.
Diels L., Pritzel E. Fragmenta Phytographiae Australiae occidentalis. Beiträge zur Kenntnis der Pflanzen Westaustraliens, ihrer Verbreitung und ihrer LebensVerhältnisse. Botanische Jahrbücher für Systematik, Pflanzengeschichte und Pflanzengeographie, 1905, 35: 55-662.

Domin K. Beiträge zur Flora und Pflanzengeographie Australiens: 3. Abt.: Embryophyta siphonogama, pars II: Dicotyledoneae [1 Teil, 3 Abteilung, Lieferung 1]. Bibliotheca Botanica, 1921, Band 22, Heft 89': 555-643 [parallel pagination: 1-89].

Duretto M.F., Morris D.I. Amaranthaceae, version 2011:1. In: Flora of Tasmania Online. Ed. M.F. Duretto. Hobart: Tasmanian Herbarium, Tasmanian Museum \& Art Gallery, 2011, 29 pp. Available from: www. tmag.tas.gov.au/floratasmania and http://demo1. tmag.tas.gov.au/treatments/families/Amaranthaceae/ Amaranthaceae_2011_1.pdf, accessed 26 January 2018.

Ebach M.C. Reinvention of Australasian Biogeography: Reform, Revolt and Rebellion. Clayton South VIC, Australia: CSIRO Publishing, 2017, xii + 179 pp.

Eriksson O., Kiviniemi K. Evolution of plant dispersal. In: Life history evolution in plants. Eds. T.O. Vuorisalo, P.K. Mutikainen. Dordrecht: Kluwer Academic Publishers, 1999, pp. 215-238.

Esler A.E., Astridge S.J. The naturalisation of plants in urban Auckland, New Zealand. 2. Records of introduction and naturalisation. New Zealand Journal of Botany, 1987, 25: 523-537.

Fawcett W. Apetalae (pp. 515-518 in: Prodromus Florae Timorensis: compiled in the Botanical Department of the British Museum). In: H.O. Forbes. A naturalist's wanderings in the Eastern archipelago. A narrative of travel and exploration from 1878 to 1883. New York: Harper \& Brothers, 1885, pp. 497-523.

Flinders M. A Voyage to Terra Australis: undertaken for the purpose of completing the discovery of that vast country, and prosecuted in the years 1801, 1802, and 1803 in His Majesty's ship the Investigator, and subsequently in the armed vessel Porpoise and Cumberland Schooner; with an account of the shipwreck of the Porpoise, arrival of the Cumberland at Mauritius, and imprisonment of the commander during six years and a half in that island. London: G. and W. Nicol, 1814, vols. 1-2, with an Atlas (3 vols.).

Freitag H. Salsola. In: Flora of Pakistan. Eds. S.L. Ali, M. Qaiser. Karachi: University of Karachi \& St. Louis: Missouri Botanical [Garden] Press, 2001, No. 204, pp. $127-178$.

Gaskin J.F., Ryan F.J., Hrusa G.F., Londo J.P. Genotype diversity of Salsola tragus and potential origins of a previously unidentified invasive Salsola from California and Arizona. Madroño, 2006, 53(3): 244-251. http:// dx.doi.org/10.3120/0024-9637(2006)53[244:GDOSTA] 2.0.CO;2

Grime J.P. Evidence for the existence of three primary strategies in plants and its relevance to ecological and evolutionary theory. The American Naturalist, 1977, 111(No. 982): 1169-1194.

Grime J.P., Pierce S. The evolutionary strategies that shape ecosystems. Chichester, West Sussex: John Wiley \& Sons, Ltd., 2012, xx +240 pp. 
Groves R.H., Hosking J.R., Batianoff G.N., Cooke D.A., Cowie I.D., Johnson R.W., Keighery G.J., Lepschi B.J., Mitchell A.A., Moerkerk M., Randall R.P., Rozefelds A.C., Walsh N.G., Waterhouse B.M. Weed categories for natural and agricultural ecosystem management. Canberra: Bureau of Rural Sciences, 2003, iv $+194 \mathrm{pp}$.

Grubov V.I. Chenopodiaceae. In: Plantae Asiae Centralis. Leningrad: Nauka, 1966, vol. 2, 134 pр. [Грубов В.И. Chenopodiaceae. В кн.: Растения Центральной Азии. Л.: Наука, 1966, т. 2, 134 с.].

Hernández-Ledesma P., Berendsohn W.G., Borsch T., von Mering S., Akhani H., Arias S., Castañeda-Noa I., Eggli U., Eriksson R., Flores-Olvera H., Fuentes-Bazán S., Kadereit G., Klak C., Korotkova N., Nyffeler R., Ocampo G., Ochoterena H., Oxelman B., Rabeler R.K., Sanchez A., Schlumpberger B.O., Uotila P. A taxonomic backbone for the global synthesis of species diversity in the angiosperm order Caryophyllales. Willdenowia, 2015, 45: 281-383. http://dx.doi.org/10.3372/wi.45.45301

Hill R.S. (ed.). History of the Australian vegetation: Cretaceous to Recent. Adelaide: University of Adelaide Press, 2017, ix +433 pp. (digital edition, available from www.adelaide. edu.au/press) [Original edition: Cambridge: Cambridge University Press, 1994].

Hooker J.D. Flora Novæ-Zelandiæ [Alternative title: Flora of New Zealand]. Part 1. Flowering plants. In: The botany of the Antarctic voyage of H.M. discovery ships Erebus and Terror in the Years 1839-1843: under the command of Captain Sir James Clark Ross, vol. 2, part 1. London: Lowell Reeve, 1853, xxxix + 312 pp. + LXX tab.

Hooker J.D. On the flora of Australia: its origin, affinities, and distribution: being an introductory essay to the Flora of Tasmania. London: Lovell Reeve, 1859, vii + cxxviiii pp.

Howe H.F., Smallwood J. Ecology of seed dispersal. Annual Review of Ecology and Systematics, 1982, 13: 201-228.

Hrusa G.F. Salsola [Jepson Manual Taxonomic Treatments: draft]. In: Plant Pest Diagnostics Center Annual Report 2009. Sacramento, California: California Department of Food \& Agriculture, 2009, pp. 19-22. Available from https://www.cdfa.ca.gov/plant/ppd/PDF/PPDC2009. pdf, accessed 28 January 2018.

Hrusa G.F. Salsola. In: Jepson Flora Project (eds.). Jepson eFlora, 2012-onward. Available from http://ucjeps. berkeley.edu/eflora/eflora_display.php?tid=11507, accessed 27 January 2018.

Hrusa G.F., Gaskin J.F. The Salsola tragus complex in California (Chenopodiaceae): characterization and status of Salsola australis and the autochthonous alllopolyploid Salsola ryanii sp. nov. Madroño, 2008, 55(2): 113-131. http://dx.doi.org/10.3120/0024-9637(2008)55[113:TST CIC]2.0.CO;2

Iljin M.M. Chenopodiaceae. In: Flora URSS, Ed. V.L. Komarov. Moscow \& Leningrad: Editio Academiae Scientiarum URSS, 1936, vol. 6, pp. 2-354. [Ильин М.M. Chenopodiaceae. В кн.: Флора СССР. Ред. В.Л. Комаров. М.; Л.: Изд-во АН СССР, 1936, т. 6, с. 2-354].

Jacobs S.W.L. (updated by L. Murray, 2013). Salsola australis. In: New South Wales Flora Online. 2013onward. Available from http://plantnet.rbgsyd.nsw.gov. $\mathrm{au} /$ cgi-bin/NSWfl.pl?page $=$ nswfl\&lvl $=$ sp\&name $=$ Salso la australis, accessed 26 January 2018.

Kadereit G., Borsch T., Weising K. Freitag H. Phylogeny of Amaranthaceae and Chenopodiaceae and the evolution of $\mathrm{C}_{4}$ photosynthesis. International Journal of Plant Science, 2003, 164: 959-986.

Kadereit G., Freitag H. Molecular phylogeny of Camphorosmeae (Camphorosmoideae, Chenopodiaceae): Implications for biogeography, evolution of $\mathrm{C}_{4}$-photosynthesis and taxonomy. Taxon, 2011, 60: 51-78.

Kadereit G., Gotzek D., Jakobs S., Freitag H. Origin and age of Australian Chenopodiaceae. Organisms Diversity \& Evolution, 2005, 5: 59-80. http://dx.doi.org/10.1016/j. ode.2004.07.002

Kadereit G., Lauterbach M., Pirie M.D., Arafeh R., Freitag $\mathrm{H}$. When do different $\mathrm{C}_{4}$ leaf anatomies indicate independent $\mathrm{C}_{4}$ origins? Parallel evolution of $\mathrm{C}_{4}$ leaf types in Camphorosmeae (Chenopodiaceae). Journal of Experimental Botany, 2014, 65(13): 3499-3511. https://doi. org/10.1093/jxb/eru169

Keighery G. The naturalised vascular plants of the Pilbara region, Western Australia. Records of the Western Australian Museum, Supplement, 2010, 78: 299-311.

Kirk T. On the naturalized plants of New Zealand, especially with regard to those occurring in the Province of Auckland. Transactions and Proceedings of the New Zealand Institute, 1869 [published 1870], 2: 131-146.

Laing R.M., Blackwell E.W. Plants of New Zealand. Christchurch: Whitcombe and Tombs Ltd., 1906, xii + $456 \mathrm{pp}$.

Lehmann Ch. [J.G.C.]. Plantae Preissianae sive Enumeratio plantarum quas in Australasia occidentali et meridionalioccidentali annis 1838-1841 collegit Ludovicus Preiss. Hamburgi [Hamburg]: Sumptibus Meissneri, 1844, vol. 1 , vii $+647 \mathrm{pp}$.

Macphail M. Australian Palaeoclimates: Cretaceous to Tertiary - A review of palaeobotanical and related evidence to the year 2000. CRC LEME Special Volume Open File Report 151. Bentley, Western Australia: CRC LEME, 2007, 266 pp.

Magidovich V.I., Magidovich I.P. The Age of Great Discoveries: Period I, until the mid-16 $6^{\text {th }}$ century (Essays on the history of geographic discoveries). Moscow: Astrel', 2009, 462 pp. [Магидович В.И., Магидович И.П. Эпоха великих открытий: I период, до середины XVI века (Очерки по истории географических открытий). М.: Мир энциклопедий Аванта+; Астрель, 2009. 462 с.].

Maiden J.H. The useful native plants of Australia (including Tasmania). London: Trubner and Co. \& Sydney: Turner and Henderson, 1889, viii +696 pp.

Martin H.A. Cenozoic climatic change and the development of the arid vegetation in Australia. Journal of Arid Environments, 2006, 66: 533-563.

McConnell K. The prehistoric use of Chenopodiaceae in Australia: evidence from Carpenter's Gap shelter 1 in the Kimberley, Australia. Vegetation History and Archaeobotany, 1998, 7: 179-188.

McNeill J., Barrie F.R., Buck W.R., Demoulin V., Greuter W., Hawksworth D.L., Herendeen P.S., Knapp S., Marhold K., Prado J., Prud'homme van Reine W.F., Smith J.F., Wiersema J.H., Turland N.J. International Code of Nomenclature for Algae, Fungi and Plants 
(Melbourne Code): Adopted by the Eighteenth International Botanical Congress, Melbourne, Australia, July 2011. Regnum Vegetabile, 2012, 154: 1-274.

Michalková E., Letz D.R. Salsola collina, S. kali subsp. ruthenica, S. soda, S. tragus. In: K. Marhold (ed.), IAPT/ IOPB chromosome data 18. Taxon, 2014, 63(6): 1390, E18-E20.

Miquel F.A.W. Flora van Nederlandsch Indie [alternative Latin title: Flora Indiae Batavae]. Amsterdam: C.G. van der Post \& Utrecht: C. van der Post Jr. \& Leipzig: Fried. Fleischer, 1855, vol. 1(1), xxiv + 1116 pp. + XIV tab.

Moquin-Tandon A. Chenopodearum monographica enumeratio. Parisiis [Paris]: Sumptibus Victoris Masson, 1840, ix $+182 \mathrm{pp}$.

Moquin-Tandon A. Ordo Salsolaceae. In: A. De Candolle. Prodromus Systematis Naturalis Regni Vegetabilis. Parisiis [Paris]: Apud P.-J. Loss, Bibliopolam, 1849, vol. 13(2), pp. 41-219.

Mosyakin S.L. Newtaxa of Corispermum L.(Chenopodiaceae), with preliminary comments on taxonomy of the genus in North America. Novon, 1995, 5(4): 340-353.

Mosyakin S.L. A taxonomic synopsis of the genus Salsola L. (Chenopodiaceae) in North America. Annals of the Missouri Botanical Garden, 1996, 83: 387-395. http:// dx.doi.org/10.2307/2399867

Mosyakin S.L. Corispermum. In: Flora of North America north of Mexico. Ed. by Flora of North America Editorial Committee. New York; Oxford: Oxford University Press, 2003a, vol. 4, pp. 313-320.

Mosyakin S.L. Salsola. In: Flora of North America north of Mexico. Ed. by Flora of North America Editorial Committee. New York; Oxford: Oxford University Press, 2003b, vol. 4, pp. 398-403.

Mosyakin S.L. Systematics, phytogeography and genesis of the family Chenopodiaceae Vent. Dr. Sci. (Biol.) Dissertation: Kyiv, 2003c, 525 рр. [Мосякін С.Л. Систематика, фітогеографія та генезис родини Chenopodiaceae Vent. Дис. докт. біол. наук. Київ, 2003, 525 с.].

Mosyakin S.L. The first record of Salsola paulsenii (Chenopodiaceae) in Ukraine, with taxonomic and nomenclatural comments on related taxa. Ukrainian Botanical Journal [Український ботанічний журнал], 2017а, 74(5): 409420. https://doi.org/10.15407/ukrbotj74.05.409

Mosyakin S.L. Taxonomic and nomenclatural notes on Pontic-Mediterranean coastal and some Australasian taxa of Salsola (Chenopodiaceae). Ukrainian Botanical Journal [Український ботанічний журнал], 2017b, 74(6): 521531. https://doi.org/10.15407/ukrbotj74.06.521

Mosyakin S.L., Bezusko L.G., Mosyakin A.S. Origins of native vascular plants of Antarctica: Comments from a historical phytogeography viewpoint. Cytology and Genetics, 2007, 41(5): 308-316. https://doi.org/10.3103/ S009545270705009X

Mosyakin S.L., Freitag H., Rilke S. Kali versus Salsola: the instructive story of a questionable nomenclatural resurrection. Israel Journal of Plant Sciences, 2017, 64: 18-30. http://dx.doi.org/10.1080/07929978.2016.1256 135

Mosyakin S.L., Iamonico D. Nomenclatural changes in Chenopodium (incl. Rhagodia) (Chenopodiaceae), with considerations on relationships of some Australian taxa and their possible Eurasian relatives. Nuytsia, 2017, 28: $255-271$.

Mosyakin S.L., Rilke S., Freitag H. Proposal to conserve the name Salsola (Chenopodiaceae s. str.; Amaranthaceae sensu APG) with a conserved type. Taxon, 2014, 63: 1134-1135. https://doi.org/10.12705/635.15

Mueller F.J.H., von. Second systematic index of the plants of Victoria, comprising those which were examined between September, 1853, and October, 1854 [Victoria - Second General Report of the Government Botanist on the vegetation of the Colony]. Melbourne: John Ferres, Government Printer, 1854, 20 pp.

Mueller F. [F.J.H.], von. Iconography of Australian salsolaceous plants, 9 [ninth decade]. Melbourne: Robert S. Brain, Government Printer, 1891, tab. LXXXI-XC.

Murphy D.J., Crayn D.M. Australian comparative phytogeography: A review. In: Handbook of Australasian biogeography. Ed. M.C. Ebach. Boca Raton (Florida, US); London(UK); New York: CRC Press, 2017, pp. 129-153.

Northern Territory Herbarium (project management: I. Cowie, D. Lewis). FloraNT - Northern Territory flora online. Palmerston, N.T.: Department of Land Resource Management, 2013-onward. Available from http:// eflora.nt.gov.au/home, accessed 4 February 2018.

Pearson M. Great Southern Land: the maritime exploration of Terra Australis. Canberra: The Australian Government, Department of the Environment and Heritage, 2005, iv $+155 \mathrm{pp}$.

Petrie D. Occurrence of Zoysia pungens (Willd.) in Central Otago. New Zealand Journal of Science 1885, 2(9): 454.

Petrie D. List of the flowering plants indigenous to Otago, with indications on their distribution and range in altitude. Transactions and Proceedings of the New Zealand Institute, 1895 [issued 1896], 28 (11 in New Ser.): 540-591.

Piirainen M., Liebisch O., Kadereit G. Phylogeny, biogeography, systematics and taxonomy of Salicornioideae (Amaranthaceae/Chenopodiaceae) - A cosmopolitan, highly specialized hygrohalophyte lineage dating back to the Oligocene. Taxon, 2017, 66(1): 109-132.

Rilke S. Revision der Sektion Salsola s.l. der Gattung Salsola (Chenopodiaceae). Bibliotheca Botanica, 1999, 149: 1-190.

Ryan F.J., Ayres D.R. Molecular markers indicate two cryptic, genetically divergent populations of Russian thistle (Salsola tragus) in California. Canadian Journal of Botany, 2000, 78: 59-67. https://doi.org/10.1139/ b99-160

Ryan F.J., Mosyakin S.L., Pitcairn M.J. Molecular comparisons of Salsola tragus from California and Ukraine. Canadian Journal of Botany, 2007, 85(2): 224229. https://doi.org/10.1139/B07-005

Schmidt S.K., Reeves F.B. Interference between Salsola kali L. seedlings: implications for plant succession. Plant and Soil, 1989, 116: 107-110.

Schönberger I., Wilton A.D., Boardman K.F., Breitwieser I., Cochrane M., de Lange P.J., de Pauw B., Fife A.J., Ford K.A., Gibb E.S., Glenny D.S., Korver M.A., Novis P.M., Prebble J.M., Redmond D.N., Smissen R.D., Tawiri K. Checklist of the New Zealand Flora - Seed Plants. Lincoln, Manaaki Whenua - Landcare Research, 2017, 393 pp. http://dx.doi.org/10.7931/P1D33B 
Schupp E.W. Dispersal ability, plant. In: Encyclopedia of biological invasions. Eds. D. Simberloff, M. Rejmánek. Berkeley; Los Angeles; London: University of California Press, 2011, pp. 159-165.

Schüssler C., Freitag H., Koteyeva N., Schmidt D., Edwards G., Voznesenskaya E., Kadereit G. Molecular phylogeny and forms of photosynthesis in tribe Salsoleae (Chenopodiaceae). Journal of Experimental Botany, 2017, 68(2): 207-223. https://doi.org/10.1093/jxb/erw432

Shepherd K.A., MacFarlane T.D., Waycott M. Phylogenetic analysis of the Australian Salicornioideae (Chenopodiaceae) based on morphology and nuclear DNA. Australian Systematic Botany, 2005, 18: 89-115.

Shepherd K.A., Waycott M., Calladine A. Radiation of the Australian Salicornioideae (Chenopodiaceae) - based on evidence from nuclear and chloroplast DNA sequences. American Journal of Botany, 2004, 91: 1387-1397.

Smith L., Hrusa G.F., Gaskin J.F. How many species of Salsola tumbleweeds (Russian thistle) occur in the Western USA? In: Proceedings of the XIII International Symposium on Biological Control of Weeds, Waikoloa, Hawaii, USA, 11-16 September, 2011. Hilo, USA: USDA Forest Service, Pacific Southwest Research Station, Institute of Pacific Islands Forestry, 2013, p. 177.

Spanoghe J.B. Prodromus florae timorensis [Part 2]. Linnaea, 1841, 15: 314-350.

Stallings G.P., Thill D.C., Mallory-Smith C.A., Lass L.W. Plant movement and seed dispersal of Russian thistle (Salsola iberica). Weed Science, 1995, 43: 63-69.

Steudel E.T. Nomenclator botanicus, seu: Synonymia plantarum universalis, enumerans ordine alphabetico nomina atque synonyma, tum generica tum specifica, et a Linnaeo et a recentioribus de re botanica scriptoribus plantis phanerogamis imposita, Editio secunda ex novo elaborata et aucta [Ed. 2]. Stuttgardtiae [Stuttgart] \& Tubingae [Tubingen]: Typis et sumptibus J.G. Cottae, 1841, vol. 2, 810 pp. http://dx.doi.org/10.5962/bhl.title. 655

Stuessy T.F., König Ch., López Sepúlveda P. Paraphyly and endemic genera of oceanic islands: Implications for conservation. Annals of the Missouri Botanical Garden, 2014, 100(1-2): 50-78.

Sukhorukov A.P. The carpology of the family Chenopodiaceae in relations to problems of phylogeny, systematics and diagnostics of its representatives. Tula: Grif i K, 2014, 400 pp. [Сухоруков А.П. Карпология семейства Сhenopodiaceае в связи с проблемами филогении, систематики и диагностики его представителей. Тула: Гриф и К., 2014, 400 c.].

Sukhorukov A.P., Mavrodiev E.V., Struwig M., Nilova M.V., Dzhalilova K.K., Balandin S.A., Erst A., Krinitsyna A.A. One-seeded fruits in the Core Caryophyllales: Their origin and structural diversity. PLoS ONE, 2015, 10(2): e0117974 (38 pp.). http://dx.doi.org/10.1371/journal. pone. 0117974

Sykes W.R. Checklist of dicotyledons naturalised in New Zealand. 14. Chenopodiales and Polygonales. New Zealand Journal of Botany, 1982, 20: 325-331.

Thiers B. Index Herbariorum. A global directory of public herbaria and associated staff. New York Botanical Garden's Virtual Herbarium. 2018-onward. Available from: http://sweetgum.nybg.org/science/ih, accessed 26 January 2018 .
Toderich K.N., Shuyskaya E.N., Tana F., Ismail S., Gismatullina L.G., Li E.V. Adaptive fruit structural mechanisms of Asiatic Salsola species and its germplasm conservation and utilization. Journal of Arid Land Studies, 2012, 22(1): 73-76.

Tzvelev N.N. Notes on Chenopodiaceae of Eastern Europe. Ukrainian Botanical Journal, 1993, 50(1): 78-85. [Цвелев Н.Н. Заметки о маревых Восточной Европы. Український ботанічний журнал, 1993, 50(1): 78-85].

Tzvelev N.N. Tribe Salsoleae. In: Flora Europae Orientalis. Ed. N.N. Tzvelev. St. Petersburg: Mir i Semya-95, 1996, vol. 9, pp. 74-92. [Цвелев Н.Н. Триба Salsoleае. В кн.: Флора Восточной Европы. Ред. Н.Н. Цвелев. Санкт-Петербург: Мир и Семья-95, 1996, т. 9, c. $74-92]$.

Ulbrich E. Chenopodiaceae. In: Die natürlichen Pflanzenfamilien. Ed. 2. Eds. A. Engler, K. Prantl. Leipzig: Engelmann, 1994, vol. 16c, pp. 379-584.

Vallance T.G., Moore D.T., Groves E.W. Nature's investigator: the diary of Robert Brown in Australia, 18011805. Canberra: Australian Biological Resources Study, 2001, xii + 666 pp.

van der Pijl L. Principles of dispersal in higher plants. Ed. 3, revised and expanded. Berlin; Heidelberg; New York: Springer, 1982, $\mathrm{x}+216 \mathrm{pp}$.

van Rheede van Oudtshoorn K., van Rooyen M.W. Dispersal biology in desert plants. Berlin; Heidelberg: SpringerVerlag, 1999, xii + 242 pp.

Vittoz P., Engler R. Seed dispersal distances: a typology based on dispersal modes and plant traits. Botanica Helvetica, 2007, 117: 109-124.

Voznesenskaya E.V., Koteyeva N.K., Akhani H., Roalson E.H., Edwards G.E. Structural and physiological analyses in Salsoleae (Chenopodiaceae) indicate multiple transitions among $\mathrm{C}_{3}$, intermediate, and $\mathrm{C}_{4}$ photosynthesis. Journal of Experimental Botany, 2013, 64: 3583-3604. http://dx.doi.org/10.1093/jxb/ert191

Walsh N.G. Salsola. In: Flora of Victoria. Eds. N.G. Walsh, T.J. Entwisle. Melbourne: Inkata Press, 1996, vol. 3, pp. 197-199.

Walsh N.G., Messina A. (updated 2015). Salsola tragus. In: VicFlora: Flora of Victoria online. Royal Botanic Gardens Victoria, 2015-onward. Available from https://vicflora. rbg.vic.gov.au/flora/taxon/f5bf6bf2-dbb2-40f4-ad3d7331d7ad3358, accessed 26 January 2018.

Welles S.L., Ellstrand N.C. Rapid range expansion of a newly formed allopolyploid weed in the genus Salsola. American Journal of Botany, 2016a, 103(4): 663-667. http://dx.doi.org/10.3732/ajb.1500430

Welles S.R., Ellstrand N.C. Genetic structure reveals a history of multiple independent origins followed by admixture in the allopolyploid weed Salsola ryanii. Evolutionary Applications, 2016b, 9: 871-878. https:// dx.doi.org/10.1111\%2Feva.12399

Wen Z.-B., Zhang M.-L., Zhu G.-L., Sanderson S.C. Phylogeny of Salsoleae s.l. (Chenopodiaceae) based on DNA sequence data from ITS, $p s b \mathrm{~B}-p s b \mathrm{H}$, and $r b c \mathrm{~L}$, with emphasis on taxa of northwestern China. Plant Systematics and Evolution, 2010, 288: 25-42. http:// dx.doi.org/10.1007/s00606-010-0310-5

Wen Z.B., Zhang M.L. Anatomical types of leaves and assimilating shoots and carbon ${ }^{13} \mathrm{C} /{ }^{12} \mathrm{C}$ isotope 
fractionation in Chinese representatives of Salsoleae s.l. (Chenopodiaceae). Flora - Morphology, Distribution, Functional Ecology of Plants, 2011, 206(8): 720-730. https://doi.org/10.1016/j.flora.2010.11.015

Wightman G.M., Short P.S. Chenopodiaceae. In: Flora of the Darwin Region. Eds. P.S. Short, I.D. Cowie. Palmerston, N.T.: Northern Territory Herbarium, Department of Natural Resources, Environment, the Arts and Sport, 2011, vol. 1, pp. 1-8. Available from: http://www. nt.gov.au/nreta/wildlife/plants_herbarium/index.html, accessed 3 February 2018.

Wilson K.L. Report of the General Committee: 20. Taxon, 2017, 66: 981. https://doi.org/10.12705/664.15

Wilson P.G. Chenopodiaceae. In: Flora of Australia. Ed. A.S. George. Canberra: Australian Government Publishing Service, 1984, vol. 4, pp. 81-317.

Wilson P.G., Chinnock R.J. Chenopodiaceae (version 1). In: Flora of South Australia (ed. 5). Ed. J. Kellermann. Adelaide: State Herbarium of South Australia, 2013, 111 pp. Available from: www.flora.sa.gov.au/ed5, accessed 26 January 2018.

Winkworth R.C., Hennion F., Prinzing A., Wagstaff S.J. Explaining the disjunct distributions of austral plants: the roles of Antarctic and direct dispersal routes. Journal of Biogeography, 2015, 42(7): 1197-1209.

Winkworth R.C., Wagstaff S.J., Glenny D., Lockhart P.J. Plant dispersal N.E.W.S. from New Zealand. Trends in Ecology and Evolution, 2002, 17(11): 514-520.

Young J.A., Evans R.A. Barbwire Russian thistle seed germination. Journal of Range Management, 1979, 32: 390-394.

Zhu G.L., Mosyakin S.L., Clemants S.E. Chenopodiaceae. In: Flora of China. Eds. Z.Y. Wu, P.H. Raven, D.Y. Hong. Beijing: Science Press \& St. Louis: Missouri Botanical Garden Press, 2003, vol. 5, pp. 351-414.

Recommended for publication by Zigmantas Gudžinskas

Submitted 04.01.2018 (revised 12.02.2018)

Мосякін С.Л. Нотатки про австралійські види Salsola (Chenopodiaceae) та визнання Salsola sabrinae, nom. et stat. nov. Укр. бот. журн., 2018, 75(1): 3-19.

Інститут ботаніки ім. М.Г. Холодного НАН України вул. Терещенківська, 2, Київ 01004, Україна

В історичному контексті проаналізовані таксономічні погляди на австралійські таксони роду Salsola sensu stricto (Chenopodiaceae). На підставі наявних свідчень зроблено висновок про те, що цей рід, ймовірно, представлений в Австралії та прилеглих районах південносхідної Азії кількома (4-5 або більше) аборигенними видами, включаючи нині визнаний вид S. australis R. Br. (також натуралізований у південно-західній частині Північної Америки та Південній Африці) і, ймовірно, споріднені з ним таксони ( $S$. macrophylla $\mathrm{R}$. Br., S. brachypteris Moq., S. australis var. strobilifera (Benth.) Domin та інші); наявність адвентивних євразійських видів також не виключена. Нова назва Salsola sabrinae Mosyakin запропонована для австралійського таксона, який був раніше описаний як $S$. tragus L. subsp. grandiflora S. Rilke (non S. grandiflora Link ex Steud.) і наводиться переважно для північних тропічних і субтропічних регіонів Австралії (північна частина Західної Австралії, Північна Територія та Квінсленд). Зазначено, що для розробки надійної таксономічної схеми для австралійських / австралазійських видів Salsola та для з'ясування питань їхньої міграції до Австралії та подальшої диверсифікації на цій території необхідні додаткові спеціальні морфологічні, молекулярно-філогенетичні та філогеографічні дослідження.

Ключові слова: Chenopodiaceae, Salsola, Salsoloideae, Австралія, біогеографія, номенклатура, систематика

\section{Мосякин С.Л. Заметки об австралийских видах Salsola} (Chenopodiaceae) и обнародование Salsola sabrinae, nom. et stat. nov. Укр. бот. журн., 2018, 75(1): 3-19.

Институт ботаники им. Н.Г. Холодного НАН Украины ул. Терещенковская, 2, Киев 01004, Украина

В историческом контексте проанализированы таксономические взгляды на австралийские таксоны рода Salsola sensu stricto (Chenopodiaceae). На основании имеющихся свидетельств, сделан вывод о том, что этот род, вероятно, представлен в Австралии и прилегающих районах Юго-Восточной Азии несколькими (4-5 или более) аборигенными видами, включая ныне признанный вид S. australis R. Br. (также натурализованный в юго-западной части Северной Америки и в Южной Африке) и, очевидно, родственные таксоны ( $S$. macrophylla $\mathrm{R}$. Br., $S$. brachypteris Moq., S. australis var. strobilifera (Benth.) Domin и другие); наличие адвентивных евразийских видов также не исключено. Новое название Salsola sabrinae Mosyakin предложено для австралийского таксона, который был ранее описан как $S$. tragus L. subsp. grandiflora S. Rilke (non $S$. grandiflora Link ex Steud.) и приводится в основном для северных тропических и субтропических регионов Австралии (северная часть Западной Австралии, Северная Территория и Квинсленд). Отмечено, что для разработки надежной таксономической схемы для австралийских / австралазийских видов Salsola и для прояснения вопросов их миграции в Австралию и дальнейшей диверсификации на этой территории необходимы дополнительные специальные морфологические, молекулярно-филогенетические и филогеографические исследования.

Ключевые слова: Chenopodiaceae, Salsola, Salsoloideae, Австралия, биогеография, номенклатура, систематика 